\title{
Identification of coastal emissions of methyl chloride and methyl bromide based on high-frequency measurements on Hateruma Island
}

\author{
Y. Yokouchi, * Y. NAGASHIMA, T. SAITO and H. MUKAi \\ National Institute for Environmental Studies, Onogawa, Tsukuba, Ibaraki 305-8506, Japan
}

(Received March 10, 2009; Accepted August 24, 2009)

\begin{abstract}
Hourly measurements of atmospheric methyl chloride $\left(\mathrm{CH}_{3} \mathrm{Cl}\right)$ and methyl bromide $\left(\mathrm{CH}_{3} \mathrm{Br}\right)$, as well as some other halocarbons, were performed by using automated preconcentration gas chromatography/mass spectrometry at Hateruma Island, the southernmost inhabited island in the Japanese archipelago. Our data indicate that $\mathrm{CH}_{3} \mathrm{Cl}_{\text {and }} \mathrm{CH}_{3} \mathrm{Br}$ concentrations were occasionally increased without corresponding increases of anthropogenic halocarbons, such as HCFC-22. Those nonpollution high- $\mathrm{CH}_{3} \mathrm{Cl}$ and high- $\mathrm{CH}_{3} \mathrm{Br}$ events were observed mostly when the wind was blowing at rather low speed along the shore (a partially vegetated raised coral beach). Presuming that these methyl halides were accumulated while the air mass traveled over the beach, the emission strengths of $\mathrm{CH}_{3} \mathrm{Cl}$ and $\mathrm{CH}_{3} \mathrm{Br}$ from the beach were roughly estimated to be $900 \pm 350 \mu \mathrm{g} \mathrm{m}^{-2} \mathrm{~h}^{-1}$ and $21 \pm 10 \mu \mathrm{g} \mathrm{m}^{-2} \mathrm{~h}^{-1}$, respectively. Coastal beach is likely a new important source for $\mathrm{CH}_{3} \mathrm{Cl}$ and $\mathrm{CH}_{3} \mathrm{Br}$ on a global scale.
\end{abstract}

Keywords: methyl chloride, methyl bromide, source, measurement, beach

\section{INTRODUCTION}

Methyl chloride $\left(\mathrm{CH}_{3} \mathrm{Cl}\right)$ is the most abundant halocarbon in the atmosphere, with a global average mixing ratio of about 550 ppt. Most atmospheric $\mathrm{CH}_{3} \mathrm{Cl}$ is believed to be of natural origin. Because this compound contributes to stratospheric ozone depletion, its atmospheric burden, sources, and sinks have been of a great concern (World Meteorological Organization (WMO), 1999, 2003, 2007). Because $\mathrm{CH}_{3} \mathrm{Cl}$ has an atmospheric lifetime of 1.3 years-which is long enough for hemispheric mixing, yet short enough to reflect year-to-year emission changes-the variability of $\mathrm{CH}_{3} \mathrm{Cl}$ concentration might serve as an indicator of changes in the source ecosystems, possibly caused by climate change. Thus, it is important to gain a full understanding of the natural sources and the emission mechanisms of $\mathrm{CH}_{3} \mathrm{Cl}$.

The major known sources of $\mathrm{CH}_{3} \mathrm{Cl}$ are tropical and subtropical plants (Yokouchi et al., 2000, 2002a; Saito and Yokouchi, 2006), oceans (Khalil et al., 1999; Moore, 2000), salt marshes (Rhew et al., 2000, 2002), wood-rot fungi (Watling and Harper, 1998), rice fields (Redeker $e t$ al., 2000; Redeker and Cicerone, 2004), and biomass burning (Lobert et al., 1999; Andreae and Merlet, 2001). Recent observations and model studies have provided more evidence about biogenic sources of $\mathrm{CH}_{3} \mathrm{Cl}$ in the

*Corresponding author (e-mail: yokouchi@nies.go.jp)

Copyright $\odot 2010$ by The Geochemical Society of Japan. tropics and subtropics (WMO, 2007). Three-dimensional models have suggested that two-thirds of the atmospheric $\mathrm{CH}_{3} \mathrm{Cl}$ is emitted from terrestrial sources at low latitudes (Lee-Taylor et al., 2001; Yoshida et al., 2004), and to date dozens of plant species have been identified as $\mathrm{CH}_{3} \mathrm{Cl}$ emitters (Yokouchi et al., 2002a, 2007).

Methyl bromide $\left(\mathrm{CH}_{3} \mathrm{Br}\right)$ also appears to play an important role in stratospheric ozone depletion (WMO, 1999, 2003, 2007) and has both natural and anthropogenic sources, with the main anthropogenic source being pesticides. The use of such pesticides has been greatly reduced in the last decade because of the Montreal Protocol and subsequent amendments (Yokouchi et al., 2002b; Montzka et al., 2003), making natural $\mathrm{CH}_{3} \mathrm{Br}$ sources relatively more important. The natural sources of $\mathrm{CH}_{3} \mathrm{Br}$ are less well understood than those of $\mathrm{CH}_{3} \mathrm{Cl}$, although plants, salt marshes, and the ocean have been suggested as sources (WMO, 1999, 2003, 2007).

On the basis of high-frequency monitoring data from a remote subtropical island, we present evidence that $\mathrm{CH}_{3} \mathrm{Cl}$ as well as $\mathrm{CH}_{3} \mathrm{Br}$ are emitted from coastal beaches.

\section{OBSERVATIONS}

Since March 2004, measurements of atmospheric $\mathrm{CH}_{3} \mathrm{Cl}, \mathrm{CH}_{3} \mathrm{Br}$, and other halocarbons have been conducted at a ground station on Hateruma Island (lat. $24.1^{\circ} \mathrm{N}$, long. $123.8^{\circ} \mathrm{E}$ ) as a part of a halocarbon monitoring project. Hateruma Island, which was formed by a raised coral reef, is the southernmost inhabited island in 


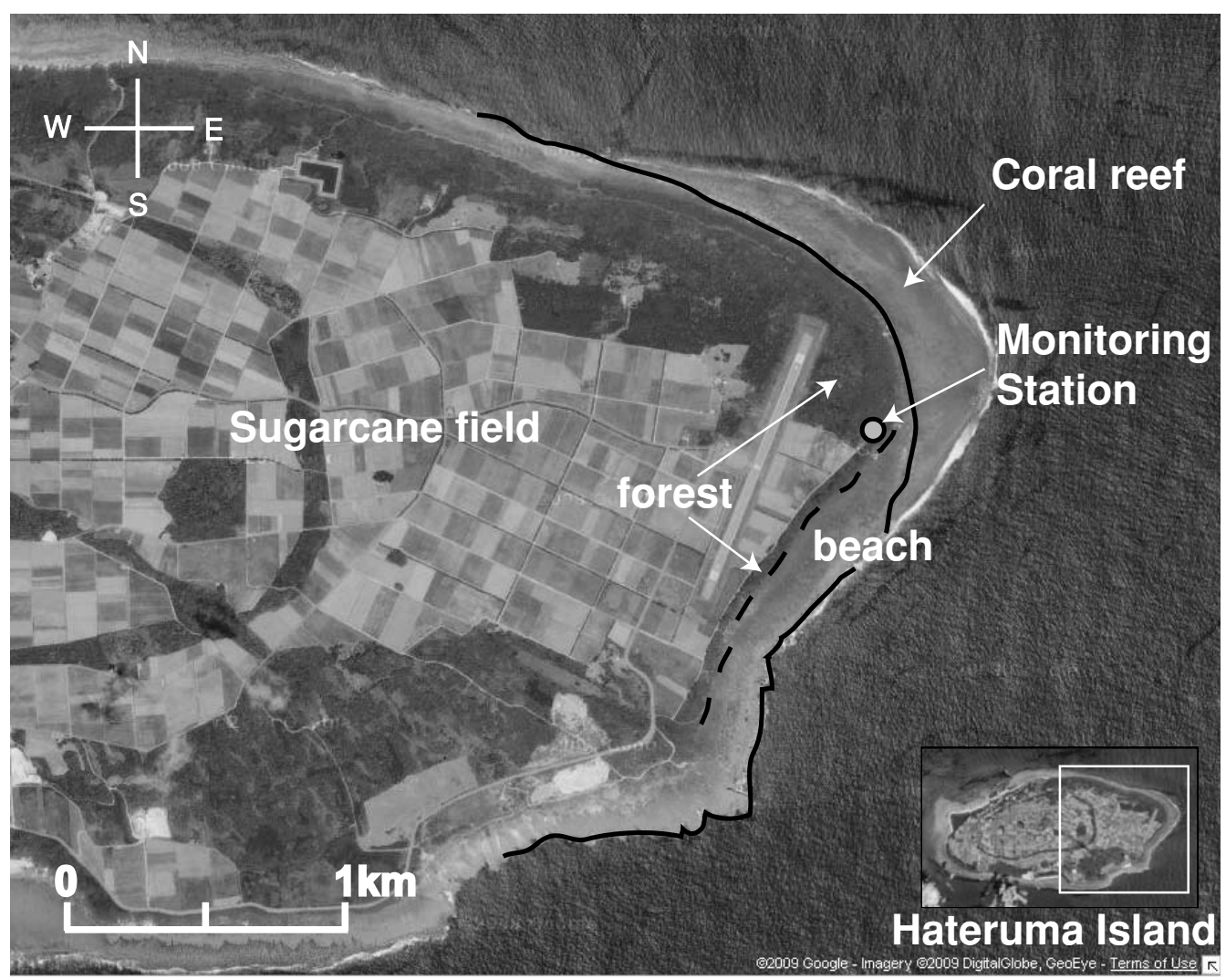

Fig. 1. Overview of Hateruma Island (lat. $24.1^{\circ} \mathrm{N}$, long. $123.8^{\circ} \mathrm{E}$ ) and the surrounding area of the monitoring station (resource: Google Map). Coastline and boundary line between forest and beach are defined with solid line and broken line, respectively.

the Japanese archipelago. The island measures about 6 $\mathrm{km}$ east-west and $4 \mathrm{~km}$ north-south, with a total area of about $12.5 \mathrm{~km}^{2}$. The island is mostly covered with sugarcane fields with scattered forests, and is surrounded by fringing coral reefs facing the open ocean. Our previous work indicated that sugarcane plants do not emit $\mathrm{CH}_{3} \mathrm{Cl}$ (unpublished). The station is located at the eastern end of the island, about $100 \mathrm{~m}$ from the shore and 10 $\mathrm{m}$ above sea level (Fig. 1). The station has a forest (1000 $\times 500 \mathrm{~m})$ to the northwest and sugarcane fields to the west and southwest. A raised coral beach with a width of 150-250 m extends south southwest from the station. Between the beach and sugarcane field, there is a thin $(\sim 50 \mathrm{~m})$ windbreak forest. The raised coral beach is covered by seashore grasses.

At the monitoring station, outside air drawn from the 40-m tower (sampling inlet: 36.5 -m-high) was analyzed every hour with an automated halocarbon measurement system based on cryogenic preconcentration and capillary gas chromatography/mass spectrometry (Enomoto et al., 2005; Yokouchi et al., 2006). After every five air analyses, a gravimetrically prepared standard gas (Taiyo Nissan Co. Ltd.) was analyzed for quantification using the same procedure as was used for the samples. In place of this regular monitoring, alternate measurements of air drawn from the 40-m tower and drawn from another 10$\mathrm{m}$ tower were conducted during May June of 2008.

\section{RESULTS AND DISCUSSION}

The dataset of $\mathrm{CH}_{3} \mathrm{Cl}$ mixing ratios from May 2004 to April 2005 is plotted in Fig. 2. The baseline mixing ratio of $\mathrm{CH}_{3} \mathrm{Cl}$ (dotted line) shows a clear seasonal variation, being lowest in autumn and highest in spring. This seasonal pattern of atmospheric $\mathrm{CH}_{3} \mathrm{Cl}$ was reported previously for the Northern Hemisphere (Khalil and Rasmussen, 1999; Yokouchi et al., 2000). The seasonal change can be explained by reaction of $\mathrm{CH}_{3} \mathrm{Cl}$ with $\mathrm{OH}$ radicals, which are more abundant during summer.

In addition to the baseline seasonal change, occasional short-term enhancements of $\mathrm{CH}_{3} \mathrm{Cl}$ mixing ratios lasting hours to days were observed. Such high-concentration events were also observed for other anthropogenic halocarbons that were measured simultaneously at the station. Our previous study indicated that short-term enhancements of hydrofluorochlorocarbons (HFCs) and hydrochlorofluorocarbons (HCFCs) at Hateruma Island were closely related to air transport from China or other 


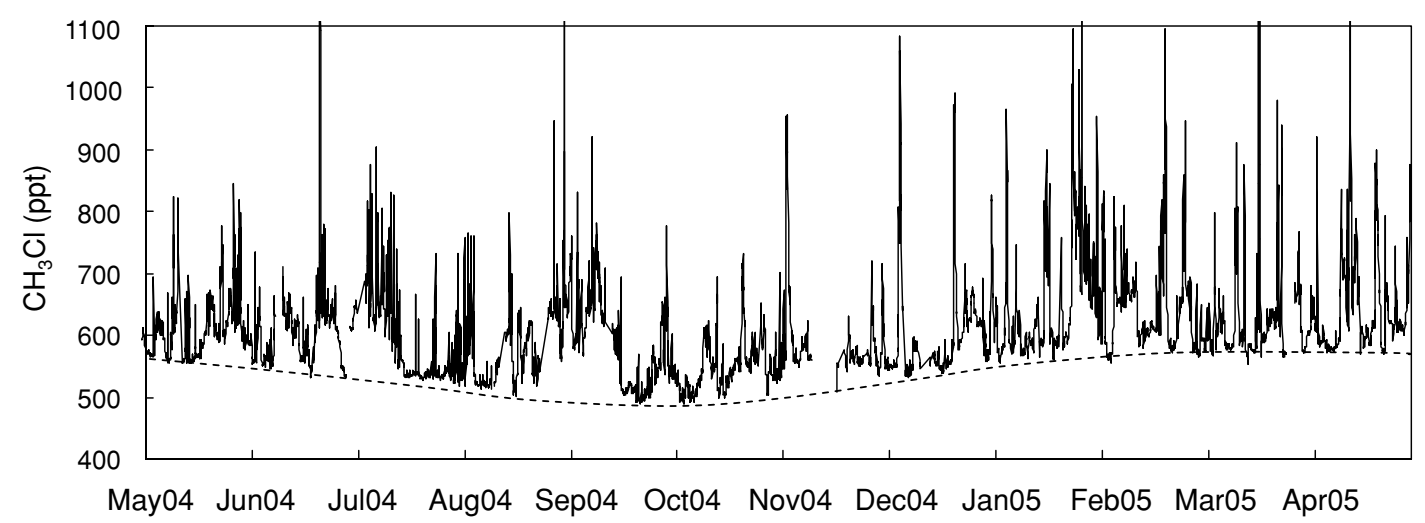

Fig. 2. Atmospheric $\mathrm{CH}_{3} \mathrm{Cl}$ mixing ratios observed at Hateruma Island from May 2004 to April 2005.
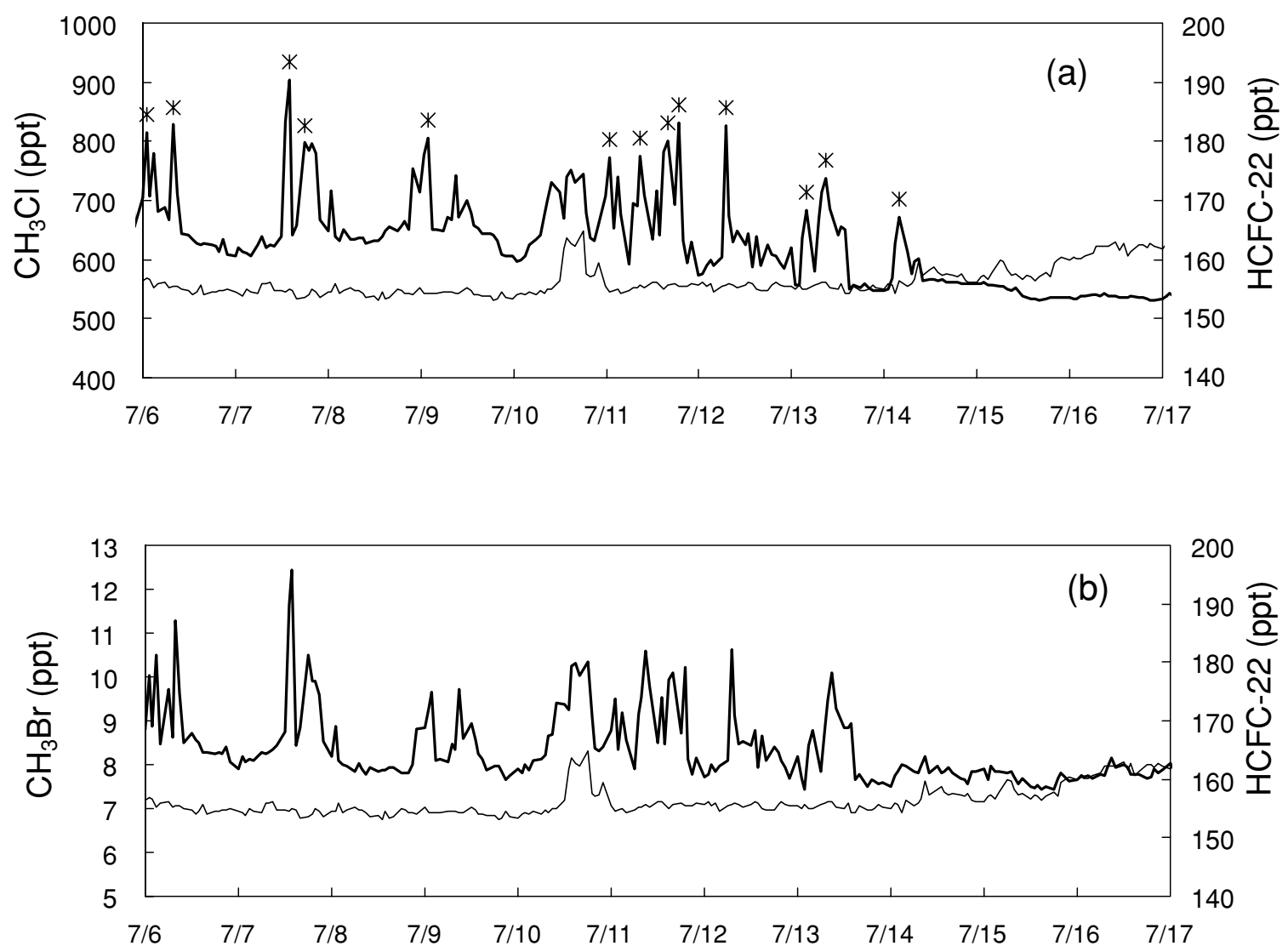

Fig. 3. (a) $\mathrm{CH}_{3} \mathrm{Cl}$ (thick line) and $\mathrm{HCFC}-22$ (thin line) mixing ratios during the nonpollution period in the summer (6-17 July 2004). The occasional enhancement of $\mathrm{CH}_{3} \mathrm{Cl}$ without a simultaneous increase in $\mathrm{HCFC}-22$ was specified as a nonpollution high$\mathrm{CH}_{3} \mathrm{Cl}$ event, each of which is marked with an asterisk. (b) $\mathrm{CH}_{3} \mathrm{Br}$ (thick line) and $\mathrm{HCFC}-22$ (thin line) mixing ratios during the same period as (a).

surrounding countries (Yokouchi et al., 2006). Considering that $\mathrm{CH}_{3} \mathrm{Cl}$ has anthropogenic sources such as fuel combustion, these short-term enhancements might also be attributed to the transport of pollution to the island.
Therefore, we compared the precise variation of $\mathrm{CH}_{3} \mathrm{Cl}$ with that of HCFC-22, the mixing ratio of which is closely correlated with many other anthropogenic compounds such as $\mathrm{C}_{2} \mathrm{Cl}_{4}, \mathrm{C}_{2} \mathrm{HCl}_{3}$, and HFC-134a. During the win- 
ter, short-term enhancements of $\mathrm{CH}_{3} \mathrm{Cl}$ and $\mathrm{HCFC}-22$ were generally observed at the same time, but during the other seasons, particularly summer, $\mathrm{CH}_{3} \mathrm{Cl}$ had some peaks that did not correspond to peaks of HCFC-22 (e.g., 6-17 July 2004, Fig. 3a). We considered those $\mathrm{CH}_{3} \mathrm{Cl}$ peaks to reflect natural emission sources and defined them as nonpollution high- $\mathrm{CH}_{3} \mathrm{Cl}$ events. Likewise, we com-

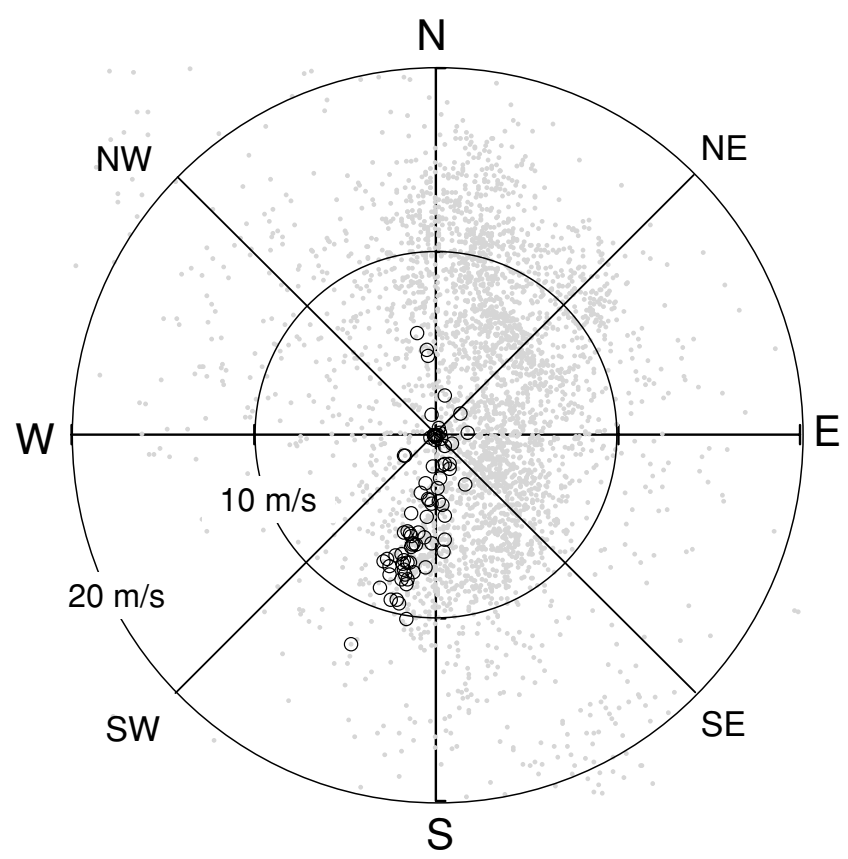

Fig. 4. Wind speed and direction observed throughout the year (gray dots) and during the nonpollution high- $\mathrm{CH}_{3} \mathrm{Cl}$ events (open circles). An arrow drawn from each point to the origin would indicate the wind vector. pared $\mathrm{CH}_{3} \mathrm{Br}$ and $\mathrm{HCFC}-22$ during the same period (Fig. $3 \mathrm{~b})$ and found that short-term enhancements of $\mathrm{CH}_{3} \mathrm{Br}$ were closely related with the nonpollution high- $\mathrm{CH}_{3} \mathrm{Cl}$ events, suggesting common sources for these $\mathrm{CH}_{3} \mathrm{Cl}$ and $\mathrm{CH}_{3} \mathrm{Br}$ emissions.

To identify the source of these nonpollution $\mathrm{CH}_{3} \mathrm{Cl}$ peaks, we investigated the wind conditions at the times those peaks were recorded. Wind speed and direction data (May 2004 to April 2005) were obtained from meteorological observation instruments at the tower top, and the heads of all the wind vectors were plotted in a direction coordinate (Fig. 4). The data corresponding to the nonpollution high- $\mathrm{CH}_{3} \mathrm{Cl}$ events (with a peak > $50 \mathrm{ppt}$ ) are designated with open circles in Fig. 4. Despite the fact that northeast or southeast winds from the ocean prevail at the station site, most of the nonpollution high$\mathrm{CH}_{3} \mathrm{Cl}$ events were observed when the wind was blowing from the south or south-southwest at rather low speed (mean: $4.6 \mathrm{~m} \mathrm{sec}^{-1}$ ). Histograms of wind speed frequency in Fig. 5 indicate that the nonpollution high- $\mathrm{CH}_{3} \mathrm{Cl}$ events are shifted toward low wind speed when compared to all the cases with south southwest wind direction or with every wind direction, suggesting local sources of $\mathrm{CH}_{3} \mathrm{Cl}$. The geographical features of Hateruma Island indicate that during these events the air masses came from along the beach. Contribution of $\mathrm{CH}_{3} \mathrm{Cl}$ emission from the thin windbreak forest adjacent to the west border of the beach was considered to be not much, since the forest is extending more west of the source distribution suggested from Fig. 4. Biomass burning, another possible source of $\mathrm{CH}_{3} \mathrm{Cl}$ and $\mathrm{CH}_{3} \mathrm{Br}$ (WMO, 2003 2007), is also not likely to be the cause of the "non-pollution high- $\mathrm{CH}_{3} \mathrm{Cl}$ events", since biomass burning is not common in this area. Thus, our data indicate that a beach as short as $1500 \mathrm{~m}$ can be a strong source of $\mathrm{CH}_{3} \mathrm{Cl}$ and $\mathrm{CH}_{3} \mathrm{Br}$ emissions.

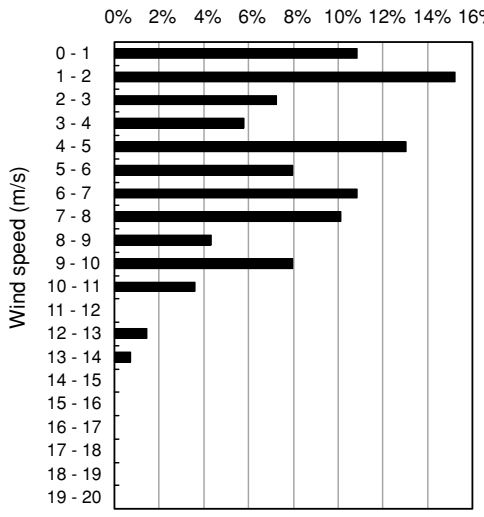

(a)

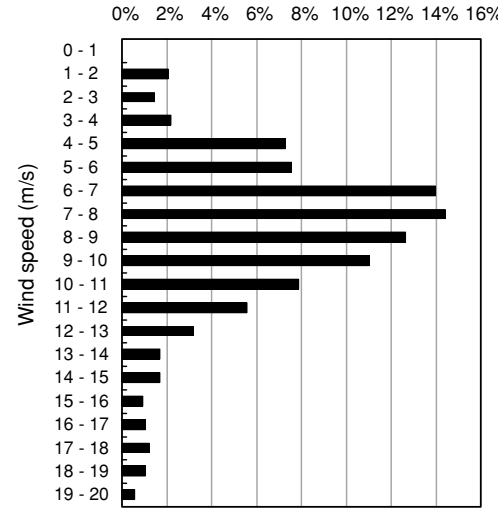

(b)

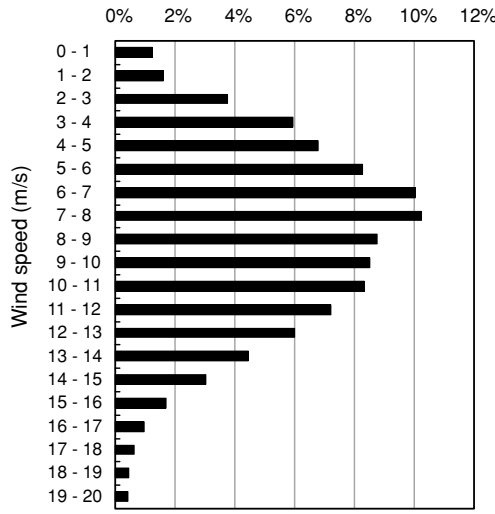

(c)

Fig. 5. Histograms of wind speed frequency for the nonpollution high-CH $\mathrm{Cl}_{3} \mathrm{Cl}$ events (a), for all the cases with south $\sim$ southwest wind direction throughout the one year $(b)$, and for all the cases with every wind direction throughout the one year $(c)$. 
In the following discussion, we try to estimate the emission strengths of $\mathrm{CH}_{3} \mathrm{Cl}$ and $\mathrm{CH}_{3} \mathrm{Br}$ from the beach, based on their atmospheric mixing ratios measured at two different heights $(36.5 \mathrm{~m}$ and $10 \mathrm{~m})$ during May-June, 2008. The observed temporal variations of the mixing ratios of the $\mathrm{CH}_{3} \mathrm{Cl}$ and $\mathrm{CH}_{3} \mathrm{Br}$ at each height are plotted in Figs. 6a and 6b, respectively, together with those of HCFC-22 as anthropogenic tracer. Figure $6 \mathrm{c}$ presents the ten-minute average data for the wind speed and direction in the same period. Both of $\mathrm{CH}_{3} \mathrm{Cl}$ and $\mathrm{CH}_{3} \mathrm{Br}$ show higher mixing ratio at $10 \mathrm{~m}$ than at $36.5 \mathrm{~m}$ in most parts of the observation, while the difference for HCFC-22 is negligible. This would be another indication of the local/natural sources of $\mathrm{CH}_{3} \mathrm{Cl}$ and $\mathrm{CH}_{3} \mathrm{Br}$. Short-term enhancements of $\mathrm{CH}_{3} \mathrm{Cl}$ (and $\mathrm{CH}_{3} \mathrm{Br}$ ) mixing ratios were more often observed for the $10 \mathrm{~m}$-samples. Among them, events $\mathrm{A} \sim \mathrm{E}$ accompanied $\mathrm{CH}_{3} \mathrm{Cl}$ (and $\mathrm{CH}_{3} \mathrm{Br}$ ) enhancement at
$36.5 \mathrm{~m}$ high, and also had no corresponding peaks of HCFC-22. The increases of $\mathrm{CH}_{3} \mathrm{Cl}$ and $\mathrm{CH}_{3} \mathrm{Br}$ from their baseline mixing ratios in these events should be reflecting their accumulation while the airmass was traveling over the beach and carrying the fresh emissions from there. If we could assume linear vertical profile of their mixing ratios as shown in Fig. 7, the increases of $\mathrm{CH}_{3} \mathrm{Cl}$ and $\mathrm{CH}_{3} \mathrm{Br}$ from their baseline mixing ratio $(\Delta \mathrm{C}(\mathrm{ppt}))$ at both of the heights (h1 (m) and h2 (m)) could be related to their accumulated amounts $\left(\Delta \mathrm{A}\left(\mu \mathrm{g} \mathrm{m}^{-2}\right)\right)$ with the following equation.

$$
\begin{aligned}
\Delta \mathrm{A}= & \left(\mathrm{h} 1 \times \Delta \mathrm{C}_{\mathrm{h} 2}-\mathrm{h} 2 \times \Delta \mathrm{C}_{\mathrm{h} 1}\right)^{2} /(\mathrm{h} 1-\mathrm{h} 2) \\
& /\left(\Delta \mathrm{C}_{\mathrm{h} 2}-\Delta \mathrm{C}_{\mathrm{h} 1}\right) / 2 \times \mathrm{M} / 22.4 / 1000,
\end{aligned}
$$

where $\mathrm{M}=$ molecular weight $\left(50.5\right.$ for $\mathrm{CH}_{3} \mathrm{Cl}, 94.9$ for $\left.\mathrm{CH}_{3} \mathrm{Br}\right), \mathrm{h} 1=36.5(\mathrm{~m}), \mathrm{h} 2=10(\mathrm{~m})$.

(a)

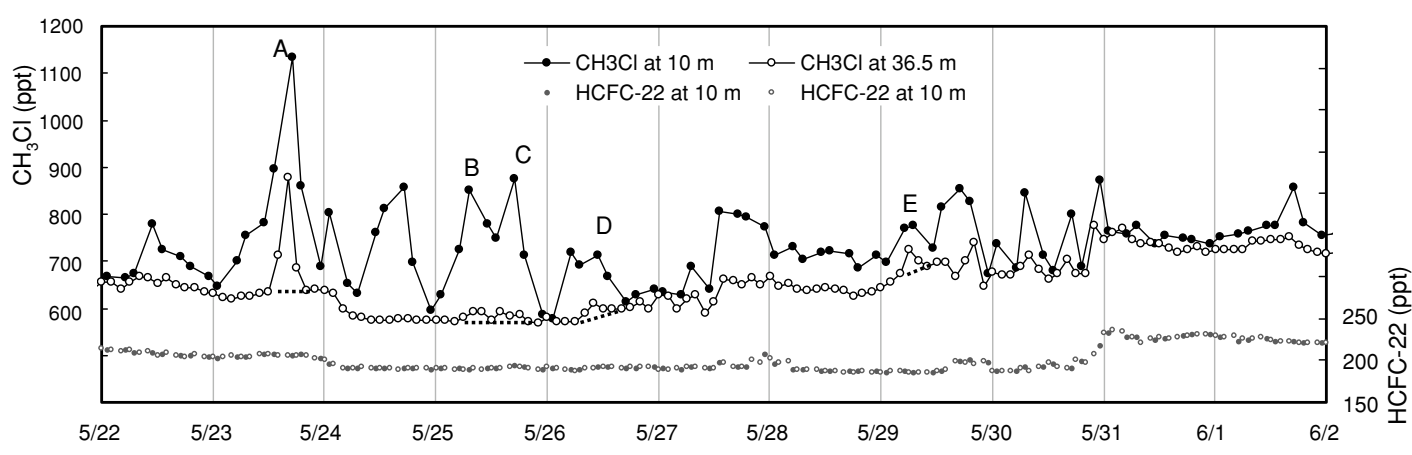

(b)

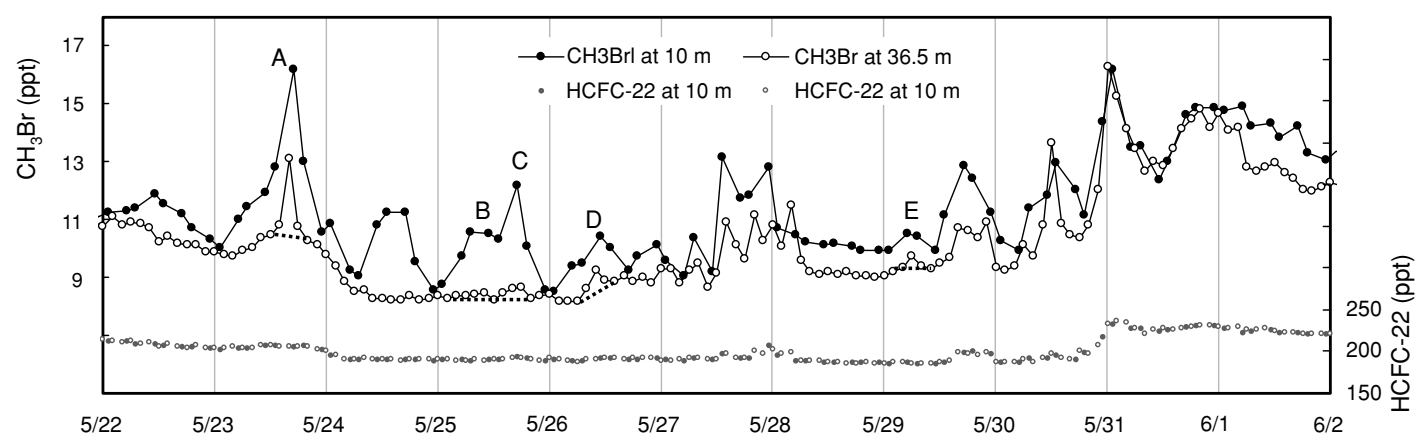

(c)

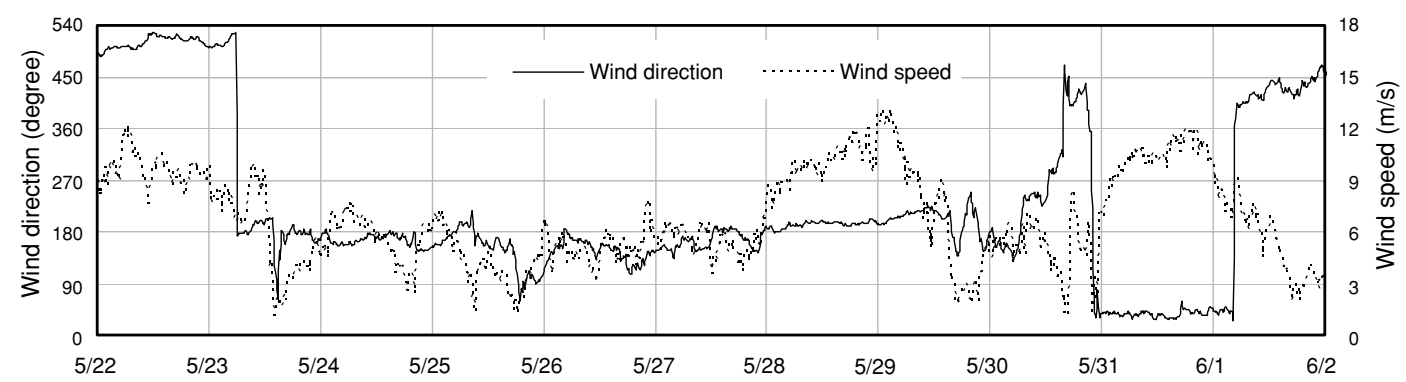

Fig. 6. (a) Mixing ratios of $\mathrm{CH}_{3} \mathrm{Cl}$ and $\mathrm{HCFC}-22$ measured at $36.5 \mathrm{~m}$ and $10 \mathrm{~m}$ high. (b) Mixing ratios of $\mathrm{CH}_{3} \mathrm{Br}$ and $\mathrm{HCFC}-22$ measured at $36.5 \mathrm{~m}$ and $10 \mathrm{~m}$ high. (c) Ten-minute average wind direction and wind speed (at $40 \mathrm{~m}$ high). Dashed lines are drawn to approximate background levels during non-pollution high events. 


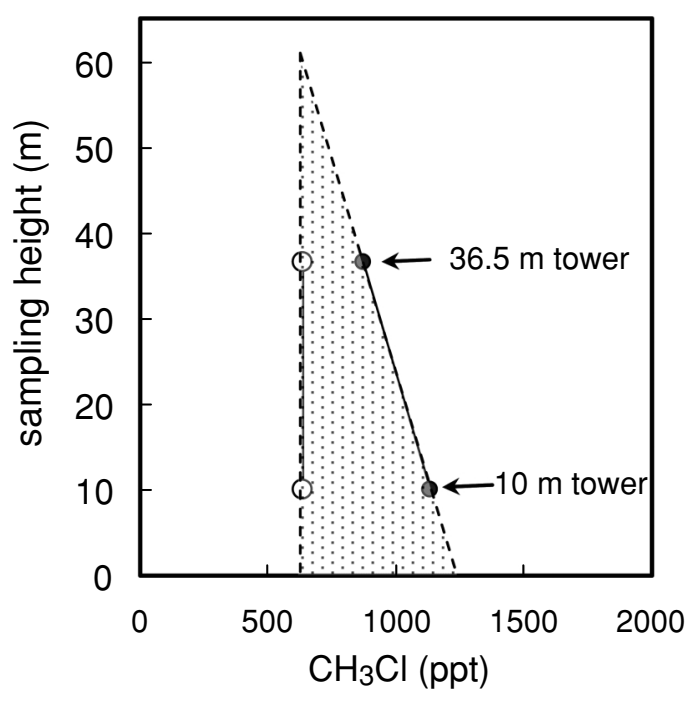

Fig. 7. A simplified model for the calculation of the increased amount at high- $\mathrm{CH}_{3} \mathrm{Cl}$ events. Solid circles: $\mathrm{CH}_{3} \mathrm{Cl}$ mixing $\mathrm{ra}$ tios measured at $10 \mathrm{~m}$ and $36.5 \mathrm{~m}$ at the event, open circles: $\mathrm{CH}_{3} \mathrm{Cl}$ baseline mixing ratio for the event (from the broken line in Fig. 6(a)), The shaded area corresponds to the accumulated amount of $\mathrm{CH}_{3} \mathrm{Cl}$ in the airmass.

The accumulated amount $\left(\Delta \mathrm{A}\left(\mu \mathrm{g} \mathrm{m}^{-2}\right)\right)$, divided by the travel time (s) over the beach, would give the emission rates $\left(\mu \mathrm{g} \mathrm{m}^{-2} \mathrm{~s}^{-1}\right)$ from the beach. The travel time could be approximated from the distance $(\mathrm{m})$ between the station and the coastline in the windward direction and the wind speed $\left(\mathrm{m} \mathrm{s}^{-1}\right)$. This simplified model was applied for each of the five events A E in Fig. 6. Since the measurements at the two heights have time-lag of one hour, and there was a slight difference in the wind data, the calculations were done for either case, and then averaged. The estimated emission rates from the beach (converted to hourly rates) - were $900 \pm 350 \mu \mathrm{g} \mathrm{m}^{-2} \mathrm{~h}^{-1}$ (570 1390 $\mu \mathrm{g} \mathrm{m}^{-2} \mathrm{~s}^{-1}$ ) for $\mathrm{CH}_{3} \mathrm{Cl}$, and $21 \pm 10 \mu \mathrm{g} \mathrm{m}^{-2} \mathrm{~h}^{-1}$ (9 29 $\left.\mu \mathrm{g} \mathrm{m}^{-2} \mathrm{~s}^{-1}\right)$ for $\mathrm{CH}_{3} \mathrm{Br}$. They could be converted to daily emissions, $22 \pm 8 \mathrm{mg} \mathrm{m}^{-2} \mathrm{~d}^{-1}$ for $\mathrm{CH}_{3} \mathrm{Cl}$ and $0.6 \pm$ $0.2 \mathrm{mg} \mathrm{m}^{-2} \mathrm{~d}^{-1}$ for $\mathrm{CH}_{3} \mathrm{Br}$. The emission estimates, however, should have greater uncertainties mostly due to the assumed simplification of the vertical profiles. Another error cause would be slightly different wind speed by altitude $(10 \sim 40 \mathrm{~m})$. Despite these uncertainties, $\mathrm{CH}_{3} \mathrm{Cl}$ emission rates per unit area from the beach does seem to be higher or similar to those from some other known terrestrial ecosystem sources: (sub)tropical forests; 12 33 $\mu \mathrm{g} \mathrm{m}^{-2} \mathrm{~h}^{-1}$ for $\mathrm{CH}_{3} \mathrm{Cl}$ (Yokouchi et al., 2007; Saito et al., 2008), rice field; $3.3 \mathrm{mg} \mathrm{m}^{-2} \mathrm{y}^{-1}$ for $\mathrm{CH}_{3} \mathrm{Cl}, 2.3 \mathrm{mg} \mathrm{m}^{-2}$ $\mathrm{y}^{-1}$ for $\mathrm{CH}_{3} \mathrm{Br}$ (Redeker and Cicerone, 2004), salt marsh; $150-550 \mu \mathrm{mol} \mathrm{m}^{-2} \mathrm{~d}^{-1}$ or $7.6 \sim 28 \mathrm{mg} \mathrm{m}^{-2} \mathrm{~d}^{-1}$ for $\mathrm{CH}_{3} \mathrm{Cl}$, $5 \sim 40 \mu \mathrm{mol} \mathrm{m}^{-2} \mathrm{~d}^{-1}$ or $0.48-3.8 \mathrm{mg} \mathrm{m}^{-2} \mathrm{~d}^{-1}$ for $\mathrm{CH}_{3} \mathrm{Br}$ (Bill et al., 2002).
As for the specific sources of $\mathrm{CH}_{3} \mathrm{Cl}$ and $\mathrm{CH}_{3} \mathrm{Br}$ on the beach, we have little information at this stage. We tested $\mathrm{CH}_{3} \mathrm{Cl}$ emission from three major species of the grasses growing on the beach using a vial method (Yokouchi et al., 2007) and found that one of them, Vitex rotundifolia L., was a high emitter of $\mathrm{CH}_{3} \mathrm{Cl}$ (emission rate: $\left.\sim 2 \mu \mathrm{g} \mathrm{g}(\text { dry weight })^{-1} \mathrm{~h}^{-1}\right)$. However, the rather small amount of plant biomass suggests that some biome other than seashore plants or non-biogenic sources might be more important for the emission of $\mathrm{CH}_{3} \mathrm{Cl}$ and $\mathrm{CH}_{3} \mathrm{Br}$ from the beach. A known abiotic formation of $\mathrm{CH}_{3} \mathrm{Cl}$ and $\mathrm{CH}_{3} \mathrm{Br}$ is the reaction of $\mathrm{Fe}(\mathrm{III})$ and organic matter in the presence of halide ions (Keppler et al., 2000). There also might be some contribution from rock pools, since parts of the coral beach are inundated by daily high-tides.

Our high-frequency observations indicated that $\mathrm{CH}_{3} \mathrm{Cl}$ and $\mathrm{CH}_{3} \mathrm{Br}$ are likely to be strongly emitted from subtropical coastal beaches. The fact that the island is covered by sugarcane, which does not emit $\mathrm{CH}_{3} \mathrm{Cl}$ and $\mathrm{CH}_{3} \mathrm{Br}$, allowed the beach emissions to be discerned. Because some remote monitoring sites are located on islands or capes, measurements of methyl halides at these sites may be affected by local coastal emissions. Considering that beaches are widely distributed in the world, "coastal beach" is likely a new important source for $\mathrm{CH}_{3} \mathrm{Cl}$ and $\mathrm{CH}_{3} \mathrm{Br}$ on a global scale. Further work is required to identify the mechanism of methyl halide production on coastal beaches and to assess the contribution of the beach sources to the global budget of $\mathrm{CH}_{3} \mathrm{Cl}$ and $\mathrm{CH}_{3} \mathrm{Br}$.

Acknowledgments - We thank Nobukazu Oda of the Global Environmental Forum for his invaluable assistance at Hateruma Station. This work was supported by the Global Environment Fund (Ministry of the Environment of Japan).

\section{REFERENCES}

Andreae, M. O. and Merlet, P. (2001) Emission of trace gases and aerosols from biomass burning. Global Biogeochem. Cycles 15, 955-966.

Bill, M., Rhew, R. C., Weiss, R. F. and Goldstein, A. H. (2002) Carbon isotope ratios of methyl bromide and methyl chloride emitted from a coastal salt marsh. Geophys. Res. Lett. 29, GL012946.

Enomoto, T., Yokouchi, Y., Izumi, K. and Inagaki, T. (2005) Development of an analytical method for atmospheric halocarbons and its application to airborne observation. $J$. Japan Soc. Atmos. Environ. 40, 1-8.

Keppler, F., Eiden, R., Niedan, V., Pracht, J. and Schöler, H. F. (2000) Halocarbons produced by natural oxidation processes during degradation of organic matter. Nature 403, 298-301.

Khalil, M. A. K. and Rasmussen, R. A. (1999) Atmospheric methyl chloride. Atmos. Environ. 33, 1305-1321.

Khalil, M. A. K., Moore, R. M., Harper, D. B., Lobert, J. M., Erickson, D. J., Koropalov, V., Sturges, W. T. and Keene, W. C. (1999) Natural emissions of chlorine-containing 
gases: Reactive Chlorine Emissions Inventory. J. Geophys. Res. 104(D7), 8333-8346.

Lee-Taylor, J. M., Brasseur, G. P. and Yokouchi, Y. (2001) A preliminary three-dimensional global model study of atmospheric methyl chloride distributions. J. Geophys. Res. 106(D24), 34221-34233.

Lobert, J. M., Keene, W. C., Logan, J. A. and Yevich, R. (1999) Global chlorine emissions from biomass burning: Reactive Chlorine Emissions Inventory. J. Geophys. Res. 104(D7), 8373-8389.

Montzka, S. A., Butler, J. H., Hall, B. D., Mondeel, D. J. and Elkins, J. W. (2003) A decline in tropospheric organic bromine. Geophys. Res. Lett. 30, 2003 GL017745.

Moore, R. M. (2000) The solubility of low molecular weight organochlorine compounds in seawater and implications for estimating the marine source of methyl chloride to the atmosphere. Chemosphere: Global Change Science 2, 95-99.

Redeker, K. R. and Cicerone, R. J. (2004) Environmental controls over methyl halide emissions from rice paddies. Global Biogeochem. Cycles 18, GB002092.

Redeker, K. R., Wang, N. Y., Low, J. C., McMillan, A., Tyler, S. C. and Cicerone, R. J. (2000) Emissions of methyl halides and methane from rice paddies. Science 290, 966-969.

Rhew, R. C., Miller, B. R. and Weiss, R. F. (2000) Natural methyl bromide and methyl chloride emissions from coastal salt marshes. Nature 403, 292-295.

Rhew, R. C., Miller, B. R., Bill, M., Goldstein, A. H. and Weiss, R. F. (2002) Environmental and biological controls on methyl halide emissions from southern California coastal salt marshes. Biogeochemistry 60, 141-161.

Saito, T. and Yokouchi, Y. (2006) Diurnal variation in methyl halide emission rates from tropical ferns. Atmos. Environ. 40, 2806-2811.

Saito, T., Yokouchi, Y., Kosugi, Y., Tani, M., Philip, E. and Okuda, T. (2008) Methyl chloride and isoprene emissions from tropical rain forest in Southeast Asia. Geophys. Res. Lett. 35, L19812.
Watling, R. and Harper, D. B. (1998) Chloromethane production by wood-rotting fungi and an estimate of the global flux to the atmosphere. Mycol. Res. 102, 769-787.

World Meteorological Organization (1999) Scientific assessment of ozone depletion: 1998. Report No. 44, Global Ozone Research and Monitoring Project, Geneva.

World Meteorological Organization (2003) Scientific assessment of ozone depletion: 2002. Report No. 47, Global Ozone Research and Monitoring Project, Geneva.

World Meteorological Organization (2007) Scientific assessment of ozone depletion: 2006. Report No. 50, Global Ozone Research and Monitoring Project, Geneva.

Yokouchi, Y., Noijiri, Y., Barrie, L. A., Toom-Sauntry, D., Machida, T., Inuzuka, Y., Akimoto, H., Li, H. J., Fujinuma, Y. and Aoki, S. (2000) A strong source of methyl chloride to the atmosphere from tropical coastal land. Nature $\mathbf{4 0 3}$, 295-298.

Yokouchi, Y., Ikeda, M., Inuzuka, Y. and Yukawa, T. (2002a) Strong emission of methyl chloride from tropical plants. Nature 416, 163-165.

Yokouchi, Y., Toom-Sauntry, D., Yazawa, K., Inagaki, T. and Tamaru, T. (2002b) Recent decline of methyl bromide in the troposphere in accordance with the Montreal Protocol phase-out schedule. Atmos. Environ. 36, 4985-4989.

Yokouchi, Y., Taguchi, S., Saito, T., Tohjima, Y., Tanimoto, H. and Mukai, H. (2006) High-frequency measurements of HFCs at a remote site in East Asia and their implications for Chinese emissions. Geophys. Res. Lett. 33, 2006 GL026403.

Yokouchi, Y., Saito, T., Ishigaki, C. and Aramoto, M. (2007) Identification of methyl chloride-emitting plants and atmospheric measurements on a subtropical island. Chemosphere 69, 549-553.

Yoshida, Y., Wang, Y. H., Zeng, T. and Yantosca, R. (2004) A three-dimensional global model study of atmospheric methyl chloride budget and distributions. J. Geophys. Res. 109, D24309, doi:10.1029/2003JD003404. 